\title{
A Case-Study of Financial Literacy and Wellbeing of Immigrants in Lloydminster, Canada
}

\author{
Oludamola Durodola ${ }^{1}$, Patricia Fusch ${ }^{2} \&$ Steven Tippins ${ }^{2}$ \\ ${ }^{1}$ Department of Business, Lakeland College, Lloydminster Alberta, Canada \\ ${ }^{2}$ School of Management, Walden University, Minneapolis, USA \\ Correspondence: Oludamola Durodola, Department of Business, Lakeland College, 2602, 59 Avenue, \\ Lloydminster Alberta. T9V3N7, Canada. E-mail: oludamola.durodola@lakelandcollege.ca
}

Received: June 11, 2017

doi:10.5539/ijbm.v12n8p37
Accepted: July 9, 2017

Online Published: July 18, 2017

\begin{abstract}
The sources of financial literacy education accessible to immigrants to Canada and the link between immigrant's financial literacy and financial decisions could impact their welfare and Canada's population growth negatively. The purpose of this qualitative exploratory case study was to explore sources of immigrant's financial literacy education immediately they arrive Canada and the link between their financial knowledge and financial decisions. The life cycle hypothesis, rational choice theory, and bounded rationality theory grounded the study. Data collection from the purposeful sample included semi-structured face-to-face interviews with 13 adult immigrants and a focus group discussion with 6 adult immigrants, all of whom lived, worked, or owned a business in the city of Lloydminster. Data was collected between December 12 and December 19 2016. Using Yin's 5 step data analytic procedure, the 6 themes that described the pattern between immigrant's wellbeing and their financial literacy levels are social institutions, economic institutions, pressure impacting financial decisions, credit facility impacting financial decisions, emotions impacting financial decisions, and discount deals impacting financial decisions. The results from this qualitative study might trigger positive social change if immigrants to Canada develop their financial literacy levels and stay committed to making sensible financial decisions.
\end{abstract}

Keywords: Financial literacy, financial decisions, population growth, immigrants, life cycle hypothesis

\section{Introduction}

Population growth is an important prerequisite for a country's healthy economic growth (Nadeau, 2011), and the Canadian government's immigration program was established to encourage economic growth in Canada. Dungan, Fang, and Gunderson (2013) noted that the inflow of immigrants into Canada has yielded significant improvement in the Canadian real gross domestic product (GDP) and GDP per capita. Immigrants are individuals or groups of people who moved either temporarily or permanently from one geographical region to another due to a range of factors such as economic and political instability (Heilbrunn, Gorodzeisky, \& Glikman 2016). The Canadian immigration program has expanded activities in the Canadian domestic labour market, eliminating the particular problem of acute skill shortages often previously observed in designated professions (Nadeau, 2011; Oreopoulos, 2011). Notwithstanding the positive contribution provided by the Canadian immigration program to the Canadian labour market, integrating into Canadian society poses a significant challenge to immigrants. Immigrants face a new macroeconomic environment, and new financial decisions (Oreopoulos, 2011).Financial literacy can curb rising debt (Keown, 2011; Steele \& Anderson, 2016). Steele and Anderson (2016) noted that because consumers are bombarded daily with a barrage of financial decisions, coupled with a financial market that offers a wide array of debt instruments, a high level of financial knowledge is required to make monetary decisions. Keown (2011), however, showed that immigrants to Canada possess an extremely low level of financial education.

Keown (2011) carried out a national survey involving Canadians ages 18 to 64 to determine their level of financial literacy. The survey was based on the 2009 Canadian Financial Capability Survey and included 14 objective questions related to inflation, interest rates, credit reports, credit ratings, stocks and risk, insurance, taxation, debts and loans, and banking fees. Canadians who took part in the survey got an average score of 64 percent, implying that they got 9 out of 14 questions correctly. Immigrants who participated in this survey had lower financial knowledge scores compared to scores of Canadians. This finding suggested that immigrants are 
deficient in basic financial literacy concepts, and therefore lack the financial knowledge needed to settle successfully in Canada. It is not clear whether the government provides sufficiently for immigrants' financial education. For example, the Financial Consumer Agency of Canada has an information section on financial literacy in a welcome guide that is typically given to newcomers once they arrive at the Canadian border. This section highlights key financial concepts such as money, taxation, banking and credits, and loans. This document represents the only available government-sponsored information resource available to newcomers to Canada (Financial Consumer Agency of Canada, 2014). Several studies have been conducted focusing on financial literacy and economic welfare. However, one notable gap in the literature is the absence of study which examines the sources of financial literacy for Canadian immigrants immediately they arrive the shores of Canada and the link between their financial education and financial decisions. This study, explores the sources of financial literacy education by Canadian immigrants immediately they arrive in Canada and also delve into possible patterns which might exist between the current level of financial literacy held by immigrants to Canada and their financial decisions. The goal is to determine whether immigrants to Canada have access to credible sources for financial education that will enable them handle their financial affairs successfully, or whether more needs to be done to help immigrants overcome financial naiveté and settle more profitably into Canadian society.

\section{Literature Review}

\subsection{Theoretical Framework}

Financial literacy revolves around the rudimentary concepts of savings and consumption; therefore, the theoretical framework of this study reflect the life-cycle hypothesis (LCH) proposed by Modigliani and Brumberg (1954). The LCH describes the ideal behavior of an individual economic agent pertaining to income, savings, and consumption from a microeconomic standpoint. According to the $\mathrm{LCH}$, an individual is expected to organize his or her savings and consumption patterns in ways that sustain marginal utility over a lifetime (Lusardi \& Mitchell, 2014). The LCH generally assumes that an individual has the required financial knowledge and sophistication necessary to orchestrate savings and consumption in a way that maximizes their utility at every point over his or her lifetime (Lusardi \& Mitchell, 2014). The LHC provides a balanced argument regarding the challenges faced when trying to decide consumption levels for now and the future (Elsayed \& Wahba 2016).

Based on current income and the prospect of future income, individuals are prone to adjust their consumption patterns in a random fashion. Typically, when income earned falls short of expectations due to macroeconomic uncertainties such as job loss, profit loss, or an economic downturn, individuals tend to consume beyond their earnings in a bid to maintain marginal utility. Then, when consumption exceeds income, the difference is captured by borrowing (Friedman, 2016; Lusardi \& Mitchell, 2014). Conversely, when income earned exceeds consumption, the excess is put away as savings against the future (Lusardi, \& Mitchell, 2014; Setterfield, \& Kim, 2016). Considering the random pattern exhibited by income, households should save in the current period to accumulate wealth that can assist in maintaining smooth consumption in the future when income falls (Modiglianni, 1966). The LCH is dynamic in time throughout the life span of an individual because household consumption and savings are not solely based on current income, but are also dependent on the future financial situation. Individual consumers, when they are young, will plan to save money in anticipation of a time in the future when they will retire from work; at that time they will want to be able to maintain their standard of living while living on their savings. In the retirement phase of life, individuals are usually constrained to consume more and save less (Friedman, 2016).

\subsection{Canadian Population and Immigration Program}

From 1960, immigration has been a significant source of population growth in countries such as Australia, New Zealand, the United States, and Canada (Bonikowska, Hou, \& Picot, 2016; Peters \& Vink 2016). Notable sources of immigrants include Africa, Asia, the Caribbean, and the Middle East (Peters \& Vink 2016). As a result of this migration trend, most developed countries at the receiving end of migrant inflow have become increasingly diverse in culture and ethnicity (Morissette \& Galarneau, 2016; Peters \& Vink 2016). Immigration is considered to be the defining identity for Canada, and a significant component of Canada's nation building strategy (Amoyaw \& Abada, 2016). Immigrants come to Canada because they were sponsored by families within Canada; because they are internationally trained; because they are refugees, temporary foreign workers, live-in caregivers, business immigrants, or protected persons; or because they are humanitarian and compassionate cases, foreign students or provincial nominees (Mukhtar, Dean, Wilson, Ghassemi, \& Wilson 2016).

The average arrival rate of immigrants to Canada was around 250,000 per year, making Canada one of the most attractive destinations for immigrants from all over the world (Citizenship and Immigration Canada, 2016). 
Anecdotal evidence shows that immigrants represent over 20 percent of the total Canadian population, the highest proportion among the G8 countries (Citizenship and Immigration Canada, 2016). The sustenance of meaningful growth of the Canadian economy hinges on the success of the Canadian immigration program (Avni, 2012). Because the Canadian labor market is characterized by skill shortages in designated professions, skilled immigrants present the most effective way of filling the vacuum (Avni, 2012). By filling the vacuum, production bottlenecks are improved, thereby causing positive growth in the Canadian GDP per capita (Dungan et al., 2010; Nadeau, 2011).

On the demand side of the economy, an influx of immigrants naturally stimulates aggregate demand across all sectors of the economy, ranging from consumables to real estate (Dungan et al., 2010). On the supply side of the economy, an influx of immigrants leads to an increase in the volume of transactions and economic activities (Dungan et al., 2010). Immigrants who join the workforce provide an increase in tax revenue for the government (Dungan et al., 2010). An influx of young families as immigrants helps to balance an ageing population, as is the case in Canada.

According to the Canadian immigration guidelines, immigrants landing in Canada must come with unencumbered funds for personal upkeep pending the time they will secure paying jobs (Citizenship and Immigration Canada, 2016). Dungan et al. (2010) observed that 100,000 immigrants who arrived Canada in 2009 brought in $\$ 1.1$ billion as foreign capital inflow which serves as an injection into the Canadian system. Immigrants also contribute to innovation in Canada by virtue of their international experience (Dungan et al., 2010).

Immigrants admitted to Canada under the business category have had direct positive impact on GDP growth through capital inflow and through using cash injections to start businesses that also create jobs (Green, Liu, Ostrovsky, \& Picot, 2016). Green et al. (2016) noted that the rate at which entrepreneurial driven immigrants start businesses is higher than the rate Canadian born counterparts start businesses. In other words, the propensity to be self-employed is higher among immigrants than among Canadian born individuals. Canada's immigration program is designed to deliver an economic advantage for Canada within the global market. As such, a majority of immigrants admitted to Canada have choice skill sets, high levels of education, and are still very energetic and active in the labor market (Amoyaw \& Abada, 2016; Fuller \& Martin, 2012). From the foregoing discussion, it is clear that immigrants in Canada impact the Canadian economy positively (Dungan et al., 2010), and that immigrants are important in the future competitive positioning of Canada in the global market (Avni, 2012).

\subsection{Financial Literacy and Well-Being}

Financial literacy refers to the appropriate application of the knowledge of financial concepts to make informed, effective and productive decisions regarding money matters (Atkinson \& Messy 2012; Capuano \& Ramsay, 2011). A plethora of studies have examined the link between financial literacy and financial behavior. For consumers in the United States, there exists a statistically significant relationship between financial knowledge and financial practices. Consumers who know more about cash-flow management, credit management, savings and investment make better decisions about money matters. These informed consumers tend to exhibit good savings habit, pay off outstanding loans and possess excellent credit score (Hilgert, Hogarth, \& Beverly, 2003). Similarly, Sarnovics, Mavlutova, Peiseniece, and Berzina (2016) noted that consumers who were well grounded in basic financial knowledge were better investors, were able to manage their debt responsibly, and were able to carry out appropriate budgeting.

In the case of New Zealand, small businesses stand a good chance of survival and growth only if their managers possess certain basic financial literacy skills such as cash budgeting, cash flow management, interest rate and inflation. These basic financial skills are helpful when making decisions pertaining to how to finance businesses and how to avoid insolvency (Samkin, Pitu, \& Low 2014). In Uganda, Small and medium scale enterprises (SMEs) stand a good chance of having their loan application approved if the bank consider them to be well equipped to handle financial decisions effectively (Korutaro Nkundabanyanga, Kasozi, Nalukenge, \& Tauringana 2014). Financial literacy plays an influential role on the outcome of a financial product marketing campaign. Consumers who are knowledgeable about financial concepts tend to respond better to financial product marketing campaign by financial institutions. Meanwhile consumers who are financially illiterate may struggle to understand product attributes and benefit and as such may respond negatively to such campaign (DeArmond 2010).

Consumers who are financially naïve end up being exploited by credit card issuing banks by luring them into signing up for credit cards with high interest rate. Meanwhile, consumers having excellent financial knowledge 
more often than not end up with low cost, high benefit credit cards. This finding implies that consumers who are ignorant of financial concepts end up accumulating debt excessively due to apparent poor choices (Ricaldi, Finke, \& Huston 2013). The foregoing finding further suggests that financial literacy is a critical requirement in the choice of suitable and cost effective debt instruments. In the same vein, Allgood and Walstad (2011) contended that a significant relationship exists between financial literacy and credit card behavior. In India, financial inclusion is attainable within an economy if the financial literacy level is improved upon nationally. Financial inclusion in this case is defined as the percentage of the entire population with access to banking services as opposed to those without banking privileges (Raina 2014). The Indian society generally is characterized by low level of financial literacy. Particularly, certain demographic groups such as women, individuals with low level education, low income families, ethnic minorities and aged population have been observed to possess extremely low level of financial literacy. This observation has consequently led to an extreme case of financial exclusion where a significant percentage of the population remains unbanked. This analysis further suggests that because financial literacy could contribute positively to economic and social development, the Reserve Bank of India has a responsibility to promote financial literacy (Singh, 2014).

Evidence from the United States, the Netherlands and Germany suggests that financial literacy was lower for women when compared with men. Because women tend to live longer than men, low financial literacy for women imply that women who have retired or advanced in age might end up making poor choices regarding financial decisions which is typically accompanied by economic hardship (Bucher-Koenen, Lusardi, Alessie, \& Van Rooij, 2014).

The current level of financial literacy in Australia has improved significantly compared to a decade ago. Considering the recent proliferation of a wide array of financial instruments within the banking sector and the aggressive marketing antics exhibited by financial services providers across the country, there is still room for improvement (Worthington 2013).

Financial literacy affects the prevention of homelessness in Australia. Financially literate individuals are well equipped to organize their finances such that late or no payment of their mortgage obligation is avoided. Furthermore, financial counselling and financial training could alleviate the negative effect of psychological stress experienced by families having financial challenges. The quality of financial education received also improved the ability of families to manage their finances and helped them to cope with economic instability (Steen \& Mackenzie 2013). There is a strong association between financial literacy and consumer behaviour for decisions pertaining to financial product for consumers in Australia. Individuals with higher levels of financial literacy behaved optimally in regard to financially related decisions. Evidence suggests that Australians in general possess reasonably high levels of financial literacy while the middle class and traditionally disadvantaged Australians possess below average financial literacy. Therefore in order to improve how consumers behave regarding the consumption of financial product, demographic group with low level of financial literacy need financial education (Capuano \& Ramsay 2011).

In the same vein, a survey of Australian University students showed a generally low level of personal finance education. There was a significant association between a student's field of study and that student's knowledge of basic financial knowledge. Students studying business as a discipline have better knowledge of finance concept relative to students in health sciences and arts. This finding supports the need for a proactive program to equip university students with appropriate level of financial education (Cull \& Whitton 2011)

Motivated by the belief that national financial security can be achieved only if citizens are financially literate, Taylor and Wagland (2011) examined existing government policies and initiatives put in place to improve financial literacy in Australia and New Zealand. Their findings showed that even though there was marginal improvement in the financial literacy level within the period under study (2008-2010) in both countries, a minority of citizens retained a low level of financial literacy. The authors recommended that more attention regarding financial literacy be directed to the disadvantaged group.

\section{Study Purpose and Research Questions}

Keown (2011) noted that a strong link exists between financial literacy and financial behaviors such as savings and demand for credit facilities. It is reasonable to assume that immigrants who arrive in Canada with little knowledge about the Canadian financial system will tend to exhibit financial behaviors that are counterproductive.

Zuhair, Wickremasinghe, and Natoli (2015) submitted that newly arrived immigrants encounter challenges with respect to accessing financial information and general handling of financial matters in their new environment. As a result, a series of ill-informed financial decisions often lead to adverse socioeconomic consequences. For 
instance, an accumulation of debt due to bad choices could prevent immigrants from achieving future important goals such as buying a house, furthering their education, and saving for retirement (Pooler, \& He, 2016; Strauss, $\&$ McGrath, 2016). Poor financial decisions may even lead to more complicated social and psychological problems such as divorce, mental illness, emotional stress, depression, and low self-esteem (Capuano \& Ramsay, 2011; O'Donovan 2016). Against this background, this paper explores the sources of financial literacy education available to Canadian immigrants immediately they arrive in Canada and also explores the applicability of their acquired financial knowledge to day-to-day financial decisions.

The study tries to answer the following questions:

1) What are the sources of financial literacy education for the immigrants?

2) How does the financial literacy level of the immigrants affect their financial decisions?

\section{Research Methodology}

For this study, we follow the qualitative approach because our central goal is to discover or explore a given phenomenon. Qualitative research enables an in-depth exploration and understanding of the interpretation provided by groups or individuals to social or human problems (Malagan-Maldonado 2014). The qualitative research tradition, also, allows the use of inductive reasoning to synthesize textual or narrative data. This method of research focuses on textual data as opposed to numerical data as is the case for quantitative research. Furthermore, qualitative research is subjective as it exposes a researcher to multiple realities regarding a given phenomenon which is subject to diverse interpretation depending on individual perspectives (Malagan-Maldonado 2014). Under the qualitative research platform, five approaches are feasible: case study, phenomenology, narrative, ethnography, and grounded theory. We used a qualitative case study approach to explore the research questions. Case study research represents an in-depth exploration of a social phenomenon embedded within practical life issues, especially in situations whereby the phenomenon and the context in which it occurs are intertwined (Yin, 2009,). Case study research follows a systematic procedure, especially where in-depth data gathering is required (Cronin, 2014). Rubaie (2002) submitted that case study research provides a robust understanding of a phenomenon that emerges from complexities linked to interpersonal activities in a wide social context. A qualitative case study is resourceful in exploratory, explanatory, and descriptive forms (Yin, 2009), and is useful in the study of contemporary events wherein relevant variables cannot be susceptible to manipulation as they can be in a controlled environment (Yin, 2009). A case study can provide a rich collection of data by enabling the researcher to directly observe and interview persons connected to the event or phenomenon of interest (Cronin, 2014; Yin, 2009).

\subsection{Analytic Procedure}

Our roles as researchers demand that we observe, gather and present honest textual data or information about the nature of the study. While interviewing participants, we took advantage of unexpected opportunities to gather data by being sensitive to responses from participants, posing questions that will elicit answers that will enrich the findings of the study. A five-step data analysis procedure presented in figure 1 below proposed by Yin (2015) forms the data analytic procedure in this research. The five steps give structure to the data to counter criticisms in the literature that case study methodology lacks universally accepted analytic structure (Cronin, 2014; Harland, 2014; DaMota Pedrosa, Naslund, \& Jasmand, 2011).

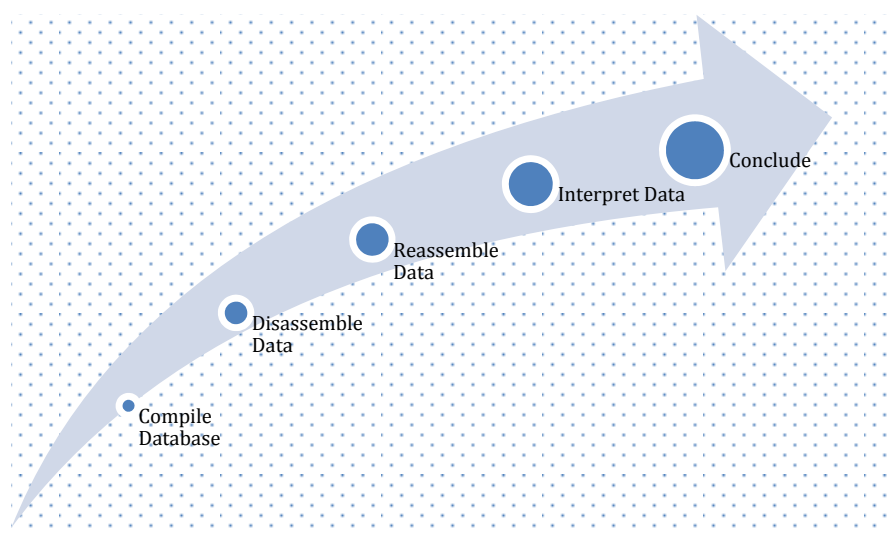

Figure 1. Five steps procedure for qualitative data analysis 
As soon as data collection is completed, the data compilation involved sorting the field notes collected from field work including the arrangement of notes that contained textual data in a meaningful order before embarking on analysis. The compilation includes rereading the transcribed notes over and over again to refresh ones' memory about the field interviews and the focus group discussions. This exercise enabled us to assimilate the information more thoughtfully at a more measured rate and gave us an opportunity to connect the data with the original research question. We were mindful of new insights into issues surrounding the research questions. Also, we watched out for certain words used by interviewees to ascertain whether they were important or should be wiped out. Finally, we placed the data into a consistent format, known as data record, which could be used for further analysis, thus completing step 1 of Yin's procedure Yin (2015).

After establishing familiarity with the textual data obtained in the field, we embarked on step 2 (Yin, 2015), disassembly. We broke down the compiled textual data into smaller fragments and assigned a label to each fragment. To compartmentalize the fragments, we identified specific field actions, specific opinions, and explanations of participants, and assigned them level 1 coding. When we noticed that some items were similar, we placed them under a broader category; we reclassified them with level 2 codes as discussed by Yin (2015).

Because of the complexity that could arise while coding, we decided to code line by line responses provided by participants during the interview and the focus group discussion. Furthermore, to make disassembling less clumsy, we avoided repetitive coding statements and participant statements that were unrelated to the questions asked during the interview. Reassembly of the data (Yin, 2015) entailed the use of substantive themes to combine fragmented items into different groups such that the new formation was different from the original note. During this phase, we attempted to identify patterns by checking to see whether different events or experiences as documented by different participants were related to each other. we checked if participants with similar demographic data were responding similarly to the same question. we followed a recursive process of mixing and matching the coded fragments under different arrangements and themes until credible and relevant patterns emerged that seemed satisfactory. After identifying credible and interesting patterns, we proceeded to step 4 (Yin, 2015), interpretation, that is, we looked for a close alliance of the data with the research questions. We scanned the reassembled data starting from the broader perspective and narrowing down in close alignment with the research objectives to bring out salient points. This alignment was necessary because two independent researchers having access to the reassembled data can come up with two totally different interpretations. After providing an extensive interpretation, we put forward a focused and concise conclusion to wrap up the five-step data analysis process described in Yin (2015).

\subsection{Instrument and Data Gathering}

Two data collection instruments were used in this study; in-depth interview and focus group discussion. The in-depth interview process entails extended discussions with research subjects, following a structured, semistructured, or unstructured pattern based on the degree of predetermination of a question sequence (Janesick, 2011). We selected the semistructured option because it enables the blend of flexibility and structure preferred by the investigator. To understand the link between financial knowledge and financial decision, we carried out focus group discussion in which the researcher raised questions for participants to analyze and discuss (Yin, 2015). We selected participants in this study via a purposive sampling method. Teddie and Tashakkori (2009) indicated that purposive sampling is not random; it involves a selection of units of analysis based on a specific purpose. In this case, we targeted immigrant individuals who reside permanently in the City of Lloydminster, Canada. Our goal was to interview maximum 20 people. Regarding the focus group size, Fusch and Ness (2015) noted that a reasonable focus group should be between 6 and 12 participants such that the group is sufficiently small for everyone to talk and share their experiences and beliefs and at the same time large enough to include a diversity of views and opinions. The nature of a focus group interview is that it enables a flexible unstructured discussion among participants in the group (Fusch \& Ness, 2015). If moderated by an experienced facilitator, the evolving discussion brings out multiple views on the topic of interest and enriches the data emerging from the study (Greenwood, Holley, Ellmers, Mein, \& Cloud, 2016). Participants in the study must be immigrants who reside permanently in the City of Lloydminster, Canada. Participants must not be Canadian born; they must have emigrated from any foreign country with the intention of settling permanently in Lloydminster, Canada. In other words, participants will not be temporary visitors to Canada and will not possess temporary study permits as international students. Qualified individuals must either possess a work permit or must have permanent residency status in Canada, or Canadian citizenship. Furthermore, to qualify for the study, an individual must be employed or own a business that produces a regular income stream. Participants in the study must be working adults, not minors or retirees. 
To recruit participants in the study, we contacted families who have moved from any part of the world and have come to live in Lloydminster, Canada. Possible places of contact were the church where we know most immigrant families worship, the center for new immigrant services managed by the City of Lloydminster government; word-of-mouth referrals could pass as a source of study participants. Upon contact with a willing participant, we scheduled a convenient time to conduct an interview and arranged for the participant to join a focus group discussion. Interviews were conducted face-to-face for all participants.

\section{Data Analysis and Results}

We conducted the interviews and the focus group discussion in a face-to-face format with the accompanying privileges of observing participants' body language and facial expressions. We captured the interviews and the focus group discussion data using a voice tracer digital audio and video recorder. All the participants involved in the study have live and physical addresses in Lloydminster, Alberta. Interviews (13 Participants) and the focus group discussion (6 participants) were conducted with participant consent at Lakeland College after 6:30 pm Mountain Time to avoid work hours. Surprisingly, participants agreed to participate at the college rather than in their homes or offices. Lakeland College is the only community-based College in Lloydminster. Before the interview, we established rapport with each participant and expressed appreciation for his/her consent to participate in the interview. We explained the interview process and how the data collected was used to each interview or focus group participant. We also informed each participant that we would email him/her a copy of the interpretation captured from the data shared by the participants for member checking. In the case of the focus group discussion, for member checking each participant had access to the audio recording after the discussion and after transcription, the interpretation assigned to the data gathered was made available to each participant to establish internal validity. We asked participants if they had questions or objections before we began the interview/focus group procedures. The interviews and the focus group discussion were scheduled and carried out between December 12 and December 19, 2016. Each interview ranged from 24-45 minutes, while the focus group discussion lasted approximately 43 minutes. . Once data collection was completed, we uploaded the textual word document into NVivo 11 Pro for further processing.

The first research question explored sources of financial literacy education for immigrants to Lloydminster, Canada. We extracted initial codes from the interview data imported into NVivo 11 Pro. We began the coding process by initiating nodes related to each unique source of financial literacy education as submitted by participants during the interview. Two major themes emerged: (a) Social institutions, and (b) economic institutions. We illustrated the themes in Table 1. The two themes are discussed further in light of the literature and the theoretical foundation that underpins this study.

Table 1. Frequency of emergent themes

\begin{tabular}{lll}
\hline Emergent Themes & $\mathrm{n}$ & $\%$ of rate of coverage \\
\hline Economic Institutions & 7 & $3.10 \%$ \\
Social Institutions & 29 & $19.91 \%$ \\
\hline
\end{tabular}

Source: Data compiled from interviews conducted in this study.

Economic institutions particularly banking institution emerged as a theme while coding the interviews with NVivo 11 Pro. The bounded rationality theory (Simon, 1956) postulates that an economic agent faces limitations in decision making by the amount of information the agent has access to. According to this theory, an individual will settle for a satisficing solution to a problem, a solution which is satisfying based on the information at the individual's disposal but is often not optimal (Wu \& Scott, 2016). In order to make better decisions, an individual will tend to search for more information. Participants in this study noted that banks provided them with information and education regarding financial concepts when they first came to Canada. Participant P6 said "when I arrived in Canada I visited a major commercial bank where I was taught how to open chequing and savings accounts, how to apply for a credit card, how to manage credit card payments without damaging my credit score, and how to pay bills online through the Internet and telephone banking" (personal communication, December 15, 2016). Participant P5 indicated that "in addition to the training I received at the bank, I also got some educational brochures to take home for further reading" (personal communication, December 16, 2016). These materials gave him extensive information regarding how the Canadian consumer financial market operates. 
While coding using NVivo 11 Pro, a unique node was created for the theme social institutions (Table 1) and the following social structures were noted by participants namely; church, families and friends, internet and media, postsecondary institutions and workplace as a source of financial literacy for immigrants to Canada. In line with the bounded rationality theory (Simon, 1956), immigrants' face limitation in economic decisions due to limited information at their disposal. Participant P2 said, "when I arrived Canada newly, a finance seminar organized by the church I was attending at that time gave me my first financial literacy training" (personal communication, December 16, 2016). Participant P4 mentioned that "fellow believers within the church helped me to understand some basic financial concepts that were new to me and which are needed to settle down in Canada" (personal communication, December 14, 2016). The quest for more information was as a result of the need by immigrants to reduce the limitations on rational decision imposed by limited information. The comments attributed to the theme church were brief and alluded to by two participants only.

Families and friends emerged as major social structures which provide newcomers to Canada with some basic information on financial literacy. This argument rests on the bounded rationality theory (Simon, 1956). To make quality decisions, an economic agent must increase his or her knowledge of the particular decision area (Conlisk, 1996). Most immigrants coming to Canada do so based on recommendations from friends and families who already reside in Canada (Mukhtar et al., 2016; Wilson 2016). When immigrants arrive in Canada, this circle of influence becomes a source of information, and the immigrants rely on this information to settle down. Interview participant P1 said, "when I moved to Canada from Jamaica, a friend who had been in Canada before me informed me about the importance of having an excellent credit score" (personal communication, December 12, 2016). This was a valuable piece of information for someone coming from Jamaica where there was nothing like a credit score or a credit history.

Participant P2 submitted that when she arrived in Canada, she made new friends who gave her hints on a range of financially related decisions needed to settle in Canada. Participants P3, P4, and P5 also mentioned that friends they met in Canada helped them learn about particular aspects of the Canadian financial landscape. Participant P6 was fortunate to have a family member who lived in Canada before she arrived and who gave her the financial information she needed to settle in Canada. The Internet and other media also surfaced among the participants interviewed as a significant source of financial education. According to Barros (2010) regarding bounded rationality theory, the antidote to eliminating limitations imposed by current knowledge on decision making is to seek more knowledge. In a bid to make better financial decisions, immigrants search for the information that they need to be comfortable in the new environment. The popularity of the Internet and social media make them common routes for information access. Participants in the study cited the Internet and traditional media such as television, magazines, newspapers, and radio as sources of financial literacy development. For instance, participant P4 said "online blogs and dedicated financial news sites were good sources of financial literacy development for me" (personal communication, December 15, 2016). Participant P5 said, "I check customers' comments on the Internet before deciding which bank to use to manage my finances" (personal communication, December 17, 2016).

Participant P6 submitted that she carried out lots of Internet searches using Google to understand financial concepts that were new to her. Participant P7 stated that he regularly reads newspapers and magazines, particularly the business and finance sections. Participant P8 indicated that she listens to radio commentaries on finance related issues, including dedicated finance channels such as CNN money and CNBC. A handful of participants commented that Postsecondary institution and workplace provided them with valuable information on basic financial concepts needed to survive while in Canada. In the quest to expand their knowledge and to prepare for a possible career switch, immigrants often enroll in a diploma program at a postsecondary institution once they arrive in Canada. Participant P4 said that "by enrolling in a business program in Canada, I had the opportunity to learn about the Canadian financial system" (personal communication, December 15, 2016). Participant P11 mentioned that coworkers, where he was working, helped him to develop his financial literacy level. Participant P7 got a job at one of the commercial banks as a financial advisor, and while training for the position he developed his financial literacy to an advanced level.

The second research question explored how financial literacy levels of immigrants affect their financial decisions. The focus group discussion was used to collect data, and the data transcribed and imported into NVivo 11 Pro for coding to search for emergent themes. There were six participants in the focus group discussion represented by participants 1-6. Four major themes identified were: (a) credit facility impact on financial decisions, (b) discount deals affecting financial decisions, (c) emotions impacting financial decisions, and (d) pressure impacting financial decisions. To assure the reliability of the findings of the qualitative study, I discuss these themes in the light of the literature and the theoretical foundation that underpins this study. I illustrated the 
themes in Table 2. The foregoing analysis and interpretation of the findings addressed the research question under study. We used the acronym FD to depict financial decision.

Table 2. Frequency of emergent themes

\begin{tabular}{lll}
\hline Emergent Themes & $\mathrm{n}$ & $\begin{array}{l}\% \text { of rate of } \\
\text { coverage }\end{array}$ \\
\hline Pressure impacting FD* & 16 & $16.46 \%$ \\
Credit facility impacting FD & 2 & $2.49 \%$ \\
Emotions impacting FD & 7 & $2.25 \%$ \\
Discount deals impacting FD & 2 & $1.23 \%$ \\
\hline
\end{tabular}

Source: Data compiled from interviews conducted in this study.

* Financial decisions.

Research regarding the relationship between financial education and financial behavior has had mixed results. While some studies indicated that financial education significantly impacts financial behavior (Hilgert et al., 2003; Lusardi \& Tufano 2015; Taylor \& Wagland 2011), others showed that financial literacy does not consistently impact financial behavior (Glaser \& Walther, 2013; Smyczek \& Matysiewicz 2015). Glaser and Walther (2013) noted that financial literacy does not always influence financial decisions; that is, an economic agent can make suboptimal financial decisions due to prevailing circumstances, not because of ignorance. Participants' responses in the focus group conducted in this study overwhelmingly showed that financial literacy does not always influence financial decisions. Individuals can make decisions that could put their finances in jeopardy, not out of naivety but due to extraneous circumstances. The themes discussed highlight emerging situations that can overrule the financial knowledge of a person who is making a financial decision. Credit facility impacting financial decisions emerged as a major theme in the focus group discussion. Participants indicated that the buy now, pay later mentality in Canada played an important role in financial decisions. Participant P10 mentioned that "the ease of obtaining credit propelled people to make financial decisions without considering the repercussions" (focus group communication, December 17, 2016).

He acknowledged that many of his purchases would not have surfaced if credit facilities were unavailable. Participant P2 agreed with this fact and mentioned that his current mortgage obligation would not have been possible back home in Jamaica where the norm is for you to build your house using your money, not borrowed funds. The foregoing argument leans on the fact that the ease of securing credit facility is an important factor responsible for high debt.

Discount deals impacting financial decisions emerged as a major theme in the focus group discussion when it was coded using NVivo 11 Pro. Discounts, or significant reductions in the regular price of items, are often used by retail stores to entice customers to purchase their products. Participants P1 and P2 observed that a discount deal could make an individual purchase items they don't necessarily need. The purchase is carried out simply because there is a massive price reduction, not because the individual has such needs. Thus, need and affordability are not criteria for the purchase; the price reduction is the sole reason for the purchase

Emotions impacting financial decisions emerged as a major theme in the focus group discussion that was coded using NVivo 11 Pro. One argument that was consistent among participants was the link between spontaneous reaction and emotion driven financial decision. Suboptimal financial decisions can be propelled by emotion, especially among women, according to participant P3. Participant P5 mentioned that an individual in a depressed state of mind might suddenly consider going shopping to lift his or her spirits. Participant P6 pointed out that "our decisions are often driven by feelings" (focus group communication, December 17, 2016). Especially when important celebrations for us or our loved ones are approaching, we want to spend regardless of whether it is our money or borrowed money.

Spending without a prior plan is spontaneous spending, and often such spending is performed without mapping out a payment plan. Participants P3 and P5 submitted that buying on impulse could be dangerous and could put an individual in a financial mess. Participant P6 noted that some impulse spending could be traceable to emotional issues, and family pressure, whereby a family member requests immediate assistance.

Pressure impacting financial decisions emerged as a major theme in the focus group discussion when it was coded using NVivo 11 Pro. Overwhelming evidence among participants also pointed to habits having strong 
influence as a significant pressure point. Pressure, here, refers to social forces such as family and friends, people who have a strong influence on an individual's financial decisions. During the focus group discussion, pressure was a popular theme which resonated across the spectrum of participants. Participant P1 contended that pressure often propels spending decisions, even though the decision does not make sense from a financial perspective. Participant P2 was more direct. She said "family members back home believe that their relative in Canada is doing exceptionally well and as such should be able to assist them financially when they have a need, even when I don't have cash, family members often put me under pressure to withdraw cash from my credit card, incurring huge interest costs" (focus group communication, December 17, 2016).

Participant P3 submitted that "even the church can pressure an individual for donations" (focus group communication, December 17, 2016). Participant P5 pointed out that the pressure is higher for a man with family responsibilities. Participant P6 noted that pressure often mounts during festive seasons, such as Christmas when there is a pressing need to give gifts to loved ones. Participant P4 added social trends to the list of financial pressures. He observed that there was pressure to upgrade a phone, for example, not because it malfunctions but because a new version is available and everyone else is upgrading.

A habit is a consistent pattern of behavior which eventually becomes a way of life. Participant P1 noted that once a spending event becomes a habit, even if it is expensive to maintain it will be repeated regardless of whether it makes sense in terms of financial literacy. In his opinion, once an individual imbibes a spending habit financial literacy becomes useless. Participant P2 gave an example: "if an individual develops a habit of eating at an expensive restaurant, even though it is cheaper to eat at home such individual will keep spending to maintain the lavish lifestyle" (focus group communication, December 17, 2016). Habit thus becomes a strong influencer when it comes to financial decisions.

\section{Conclusions and Discussion}

An improved wellbeing of immigrants in Canada could boost the Canadian government's effort to grow the Canadian population and the economy through a proactive immigration program (Dungan et al., 2013). The findings in this study showed that the immigrants participating in the study gained access to financial literacy training from diverse formal and informal sources which further suggests that immigrants access financial literacy education from questionable sources characterized by the provision of inaccurate and unreliable information. If the government could provide financial literacy education to immigrants following a systematic curriculum, immigrants could be equipped with the tools to make informed financial decisions, a situation that would impact their wellbeing positively. Since Canada has an immigrant dependent economy, this would improve Canada's wellbeing.

The Canadian government needs a more formal structure in place to equip immigrants with financial literacy when they arrive in Canada. The structure should be available in all provinces and should follow a systematic process of teaching immigrants how to survive and cope financially in their new country. Based on the findings of this study, such a structure is nonexistent. According to Citizenship and Immigration Canada (2016), immigrants aspiring to come to Canada under the Federal Skilled Trades Program must pass an English literacy test. We consider financial literacy to be of equal importance as English literacy, and as such provisions are required for immigrants' financial literacy education as well. For immigrants who have moved to Canada but need financial literacy development, the Canadian government could partner with nongovernmental organizations (NGOs) to place offices in provincial districts and communities where immigrants could receive financial literacy training as they integrate into the Canadian society.

Secondly, while exploring the interaction between the financial literacy levels of immigrants and their financial decisions, we identified four major themes. Data analyzed showed that immigrants do not always apply their financial literacy knowledge to financial decisions. In fact, one participant noted that it is one thing to have knowledge of finance, but it is a different ball game to utilize that knowledge when making financial decisions (Smyczek and Matysiewicz 2015). Canadian society, and particularly the Canadian economy, will be better off if individuals develop their financial literacy levels and apply this knowledge into making sensible financial decisions. Ohlsson (2012) submitted that the quality of financial decisions made by a household determines the household's welfare and economic wellbeing. Sound spending habits in the individual will have positive implications for Canada's gross domestic product growth, and economic development (Rooij et al., 2011). Thrifty savings habits on aggregate determine the availability of savings for investment at a national level (Ohlsson, 2012). In other words, a society that is financially literate will have a strong economy. A more pragmatic solution by the government such as the implementation and the enforcement of a formal financial education curriculum training for all immigrants before gaining access to credit could help raise immigrants' 
financial literacy level and also help lower debt levels. In addition, well-coordinated advocacy publicity by the government focusing on why rational financial decisions are important for all decisions could help lower debt levels in Canada, particularly for immigrants. On aggregate, monies adequately spent could help raise GDP growth in the appropriate sectors of the economy and create positive social change for the country as a whole.

\section{References}

Allgood, S., \& Walstad, W. B. (2011). The effects of perceived and actual financial knowledge on credit card behavior. Networks Financial Institute at Indiana State University Working Paper 2011-WP-15. http://dx.doi.rog/10.2139/ssrn.1896365

Amoyaw, J. A., \& Abada, T. (2016). Does helping them benefit me? Examining the emotional cost and benefit of immigrants' pecuniary remittance behaviour in Canada. Social Science \& Medicine, 153, 182-192. http://dx.doi.rog/10.1016/j.socscimed.2016.02.007

Atkinson, A., \& Messy, F. (2012). Measuring financial literacy: Results of the OECD / international network on financial education (INFE) pilot study Paris: Organisation for Economic Cooperation and Development (OECD). http://www.oecd-ilibrary.org/finance-and-investment/measuring-financial-literacy_5k9csfs90fr4-en

Avni, A. E. (2012). Skilled worker immigrants' pre-migration occupation re-entry experiences in Canada (Master's Thesis). Available from ProQuest Dissertations \& Theses Global. (UMI No. 1151846921).

Barros, G. (2010). Herbert A. Simon and the concept of rationality: boundaries and procedures. Brazilian Journal of Political Economy, 30, 455-472. http://dx.doi.rog/10.1590/S0101-31572010000300006

Bonikowska, A., Hou, F., \& Picot, G. (2016). New immigrants seeking new places: The role of policy changes in the regional distribution of new immigrants to Canada. Growth and Change. http://dx.doi.rog/10.1111/grow.12144

Bucher-Koenen, T., Lusardi, A., Alessie, R., \& Van Rooij, M. (2014). How financially literate are women? An overview and new insights (No. w20793). National Bureau of Economic Research. http://dx.doi.rog/10.3386/w20793

Capuano, A., \& Ramsay, I. (2011). What causes suboptimal financial behaviour? An exploration of financial literacy, social influences and behavioural economics. University of Melbourne Legal Studies Research Paper, (540). http://dx.doi.rog/10.2139/ssrn.1793502

Citizenship and Immigration Canada. (2016). Percentage of families with debt, 1999 and 2012. Retrieved from http://www.cic.gc.ca/english/about_us/reports.asp

Conlisk, J. (1996). Why bounded rationality? Journal of Economic Literature, 34, 669-700. Retrieved from https://www.aeaweb.org/journals/jel

Cull, M., \& Whitton, D. (2011). University students' financial literacy levels: Obstacles and aids. The Economic and Labour Relations Review: ELRR, 22(1), 99-114. http://dx.doi.rog/10.1177/103530461102200106

De'Armond, D. (2010). An empirical examination of financial literacy message theme effectiveness among college students: Debt or saving? Journal of Global Business Management, 6(2), 1-6. Retrieved from http://www.jgbm.org/

Dungan, P., Fang, T., \& Gunderson, M. (2013). Macroeconomic impacts of Canadian immigration: Results from a macro model. British Journal of Industrial Relations, 51(1), 174-195. http://dx.doi.rog/10.1111/j.1467-8543.2012.00905.x.

Elsayed, K., \& Wahba, H. (2016). Reexamining the relationship between inventory management and firm performance: An organizational life cycle perspective. Future Business Journal, 2(1), 65-80. http://dx.doi.rog/10.1016/j.fbj.2016.05.001

Financial Consumer Agency of Canada. (2014). National strategy for financial literacy: Count me in Canada. Government of Canada Publication. Retrieved from http://www.fcac-acfc.gc.ca/Eng/financialliteracycanada/strategy

Fuller, S., \& Martin, T.F., (2012). Predicting immigrant employment sequences in the

first years of settlement. International Migration Review, 46 (1), 138-190. http://dx.doi.rog/10.1111/j1747-7379.2012.00883.x.

Friedman, M. (2016). A theory of the consumption function. San Francisco, CA: Pickle Partners Publishing. 
Fusch, P. I., \& Ness, L. R. (2015). Are we there yet? Data saturation in qualitative research. The Qualitative Report, 20, 1408-1416. Retrieved from http://www.nova.edu/ssss/QR/QR20/9/fusch1

Glaser, M., \& Walther, T. (2013). Run, walk, or buy. In financial literacy, dual-process theory, and investment behavior. Retrieved from http://www.busman.qmul ac. uk/newsandevents/events/eventdownloads/bfwg conference 2013acceptedpapers/114912

Greenwood, N., Holley, J., Ellmers, T., Mein, G., \& Cloud, G. (2016). Qualitative focus group study investigating experiences of accessing and engaging with social care services: perspectives of careers from diverse ethnic groups caring for stroke survivors. BMJ open, $6(1)$. http://dx.doi.rog/10.1136/bmjopen-2015-009498

Green, D., Liu, H., Ostrovsky, Y., \& Picot, G. (2016). Immigration, business ownership and employment in Canada. Analytical Studies - Research Paper Series Statistics Canada-Catalogue no. 11F0019M, no. 375. Retrieved from http://www.statcan.gc.ca/pub/11f0019m/11f0019m2016375-eng.pdf

Hilgert, M. A., Hogarth, J. M., \& Beverly, S. G. (2003). Household financial management: The connection between knowledge and behavior. Federal Reserve Bulletin., 89, 309-322. Retrieved from http://www.federalreserve.gov/pubs/bulletin/2003/0703lead

Janesick, V. J. (2011). Stretching exercise for qualitative researchers (3rd ed.). Thousand Oaks, CA: Sage

Keown, L. (2011). The financial knowledge of Canadians. Components of Statistics Canada. Retrieved from http://en.copian.ca/library/research/stats/financial_knowledge/financial_knowledge.pdf.

Korutaro Nkundabanyanga, S., Kasozi, D., Nalukenge, I., \& Tauringana, V. (2014). Lending terms, financial literacy and formal credit accessibility. International Journal of Social Economics, 4, 342-361. http://dx.doi.rog/10.1108/IJSE-03-2013-0075

Lusardi, A., \& Mitchell, O. S. (2013). The economic importance of financial literacy: Theory and evidence. Journal of Economic Literature, 52(1) 5-44. http://dx.doi.rog/10.1257/jel.52.1.5

Lusardi, A., \& Tufano, P. (2015). Debt literacy, financial experiences, and overindebtedness. Journal of Pension Economics and Finance, 14, 332-368. http://dx.doi.rog/10.1017/S1474747215000232 .

Malagon-Maldonado, G. (2014). Qualitative research in health design. Herd-Health Environments Research \& Design Journal, 7(4), 120-134. http://dx.doi.rog/10.1177/193758671400700411

Modigliani, F., \& Brumberg, R. (1954). Utility analysis and the consumption function: An interpretation of cross-section data. In K. Kurihara (Ed), Post-Keynesian economics. New Brunswick, NJ: Rutgers University Press.

Morissette, R., \& Galarneau, D. (2016). Labour market participation of immigrant and Canadian-born wives, 2006 to 2014. Statistics Canada, Catalogue no. 11-626-X. Retrieved from http://www.statcan.gc.ca/pub/11-626-x/11-626-x2016055-eng.pdf

Mukhtar, M., Dean, J., Wilson, K., Ghassemi, E., \& Wilson, D. H. (2016). "But many of these problems are about fund": The challenges immigrant settlement agencies (ISAs) encounter in a suburban setting in Ontario, Canada. Journal of International Migration and Integration, 17, 389-408. http://dx.doi.rog/10.1007/s12134-015-0421-5

Nadeau, S. (2011). The economic contribution of immigration in Canada. Recent developments what do we know? What does it mean for policy? Paper presented at the Research Group on the Economics of Immigration, University of Ottawa. Retrieved from http://socialsciences.uottawa.ca/economicsimmigration/sites/socialsciences.uottawa.ca.economics-immigrat ion/files/archive_0/Synthesis_wp.pdf

O'Donovan, K. N. (2016). Financial wellness and undergraduate students. BU Well, 1(1), 10. Retrieved from http://digitalcommons.butler.edu/cgi/viewcontent.cgi?article=1011\& context=buwell

Ohlsson, C. (2012). The rhetoric of financial literacy. Journal of Interdisciplinary Economics, 24(1), 55-75. http://dx.doi.rog/10.1177/0260107912471459

Oreopoulos, P. (2011). Why do skilled immigrants struggle in the labour market? A field experiment with thirteen thousand resumes. American Economic Journal: Economic Policy, 3(4), 148-171. http://dx.doi.rog/10.1257/pol.3.4.148 
Peters, F., \& Vink, M. (2016). 19 Naturalization and the socio-economic integration of immigrants: A life-course perspective. Handbook on migration and social policy.Surrey, UK: Edward Elgar Publisher.

Pooler, J., \& He, J. (2016). Editorial: Migration: International and intranational dimensions. In Geography research forum (Vol. 23, pp. 1-3). Retrieved from http://raphael.geography.ad.bgu.ac.il/ojs/index.php/GRF/article/viewFile/256/248

Raina, N. (2014). Financial literacy and credit counselling a demand-side solution to financial inclusion (A study of initiatives by select scheduled commercial banks in India). Journal of Commerce and Management Thought, 5, 659-675. http://dx.doi.rog/10.5958/0976-478X.2014.00013.5

Ricaldi, L., Finke, M. S., \& Huston, S. J. (2013). Financial literacy and shrouded credit card rewards. Journal of Financial Services Marketing, 18(3), 177-187. http://dx.doi.rog/10.1057/fsm.2013.11

Rooij, M. V., Lusardi, A., \& Alessie, R. (2011). Financial literacy and stock market participation. Journal of Financial Economics, 101, 449-472. Retrieved from http://hdl.handle.net/10419/25528.

Samkin, G., Pitu, E., \& Low, M. (2014). Identifying the financial literacy skills necessary to run a small Newzealand business. The E - Journal of Business Education \& Scholarship of Teaching, 8(1), 44-66. Retrieved from http://www.ejbest.org/upload/eJBEST_Samkin,_Pitu_Low_-_8(1)_2014

Sarnovics, A., Mavlutova, I., Peiseniece, L., \& Berzina, S. (2016). Financial literacy enhancement as a task of financial education for Latvian population. In Business challenges in the changing economic landscape (Vol. 2. pp. 365-389). http://dx.doi.rog/10.1007/978-3-319-22593-7_27

Setterfield, M., \& Kim, Y. K. (2016). Household borrowing and the possibility of'consumption-driven, profit-led growth'. Institute for New Economic Thinking Working Paper Series, (39). Retrieved from http://repec.umb.edu/RePEc/files/2016_01

Singh, U. (2014). Financial literacy and financial stability are two aspects of efficient economy. Journal of Finance, Accounting and Management, 5(2), 59-76. Retrieved from http://www.gsmi-ijgb.com/Documents/JFAM\%20V5\%20N2\%20P04\%20Upendra\%20Singh\%20-Financial $\% 20$ Literacy\%20and\%20Financial\%20Stability

Simon, H. A. (1956), Rational choice and the structure of the environment. Psychological Review, 63(2), 129-138. doi:10.1037/h0042769

Smyczek, S., \& Matysiewicz, J. (2015). Consumers' financial literacy as tool for preventing future economic crisis. Review of Business, 36(1), 19-33. Retrieved from http://www.stjohns.edu/sites/default/files/tcb/reviewofbusinesssummer2015lr

Steele, P., \& Anderson, C. (2016). Loan counselling for graduate and professional students: The need for expanded financial literacy education. Access Group Center for Research \& Policy Analysis Research Paper (16-02). Retrieved from https://www.accessgroup.org/research

Steen, A., \& MacKenzie, D. (2013). Financial stress, financial literacy, counselling and the risk of homelessness. Australasian Accounting Business \& Finance Journal, 7(3), 31-48. doi:10.14453/aabfj.v7i3.3

Strauss, K., \& McGrath, S. (2016). Temporary migration, precarious employment and unfree labour relations: Exploring the 'continuum of exploitation' in Canada's temporary foreign worker program. Geoforum. doi:10.1016/j.geoforum.2016.01.008

Taylor, S., \& Wagland, S. (2011). Financial literacy: A review of government policy and initiatives. Australasian Accounting Business \& Finance Journal, 5(2), 101-125. Retrieved from: http://ro.uow.edu.au/aabfj/vol5/iss $2 / 7$

Worthington, A. C. (2013). Financial literacy and financial literacy programmes in Australia. Journal of Financial Services Marketing, 18, 227-240. http://dx.doi.rog/10.1057/fsm.2013.18

Wu, N., \& Scott, H. (2016). A Novel image change detection model and optimization algorithm based on game theory under the bounded rationality conditions. International Journal of Security and Its Applications 10, 317-330. http://dx.doi.rog/10.14257/ijsia.2016.10.4.29

Yin, R. K. (2015). Case study research: designs and methods (5th ed.). Thousand Oaks: Sage.

Zuhair, S., Wickremasinghe, G., \& Natoli, R. (2015). Migrants and self-reported financial literacy. International Journal of Social Economics, 42, 368-386. http://dx.doi.rog/10.1108/IJSE-09-2013-0203 


\section{Copyrights}

Copyright for this article is retained by the author(s), with first publication rights granted to the journal.

This is an open-access article distributed under the terms and conditions of the Creative Commons Attribution license (http://creativecommons.org/licenses/by/4.0/). 